\author{
Paulina Korycińska-Rządca \\ University of Bialystok \\ e-mail: p.korycinska@uwb.edu.pl \\ ORCID: 0000-0002-6177-7409
}

\title{
LEGALITY OF PROHIBITIONS ON PERFORMING SPECIFIC ECONOMIC ACTIVITIES INTRODUCED TO PREVENT THE SPREAD OF THE CORONAVIRUS SARS-COV-2: THE CASE OF POLAND
}

\begin{abstract}
State authorities have taken a variety of measures aimed at combating the COVID-19 pandemic. One group of those measures constitutes restrictions on the freedom of economic activity. In the paper the author analyses the provisions establishing prohibitions on performing specific economic activities introduced in Poland in the period from 14 March 2020 to 31 May 2021 in order to verify whether they have sufficient legal bases. For that purpose it was necessary to establish the constitutional conditions for introducing restrictions on the freedom of economic activity. Subsequently the author verified what legal bases for the implementation of the restrictions were indicated in the legal acts introducing those restrictions and how those prohibitions have been defined. The main research method used for the purpose of the paper is the dogmatic method of analysing the provisions contained in the legal acts.
\end{abstract}

Keywords: freedom of economic activity, prohibition on economic activity, COVID-19 pandemic, coronavirus SARS-CoV-2.

\section{Introduction}

The detection of the first case of coronavirus SARS-CoV-2 in Poland was reported by the Polish Health Minister during a press conference on 4 March 2020 (The Ministry of Health, 2020). Since then the Polish government has introduced a variety of measures aimed at preventing the spread of the coronavirus SARS-CoV-2.

This paper is devoted to the analysis of one group of measures taken by Polish state authorities in order to combat the COVID-19 pandemic, i.e. the prohibitions on performing specific economic activities implemented from 14 March 2020 to 31 May 2021. The purpose of this article is to find an answer to the question whether the prohibitions on performing specific 
economic activities implemented by the Polish government from 14 March 2020 to 31 May 2021 have sufficient legal bases. However, answering this question would not be possible without prior establishing of the constitutional conditions for introducing restrictions on the freedom of economic activity, as well as prior verification of which legal bases for the implementation of the restrictions were indicated in the legal acts introducing those restrictions as well as how those prohibitions have been defined. In this research, the author has mainly used the dogmatic method of analysing the provisions contained in the legal acts under which the prohibitions on performing specific economic activities were introduced as well as the legal acts that define the rules for introducing such restrictions.

\section{The prohibitions on performing specific economic activities and the freedom of economic activity}

Freedom of economic activity constitutes one element of a social market economy (Tuleja, 2021: point 1). The scope of this paper does not allow thorough analysis of the concept of the freedom of economic activity ${ }^{1}$. For the purpose of the research contained in this article it is however necessary to mention that the freedom of economic activity is most often defined as freedom from state interference in the area of human economic activity (including the right to freely start and run a business in any way and in any organizational and legal forms) and freedom from interference and difficulties on the part of other entities (e.g. competitors) (Kosikowski, 2013). It is also deemed to be the negative public right which corresponds to the general obligation of the state not to infringe upon the freedom of action of the beneficiaries of this right in the sphere of economic activity (WalaszekPyzioł, 1994: 8-13; Leszczyńska, Piszcz, 2008: 67; Garlicki, Zubik, 2016; Tuleja, 2021: point 1) $)^{2}$. In this sense this freedom constitutes the principle defining the purpose of the state's activity (Tuleja, 2021: point 1). The legal system of a given state outlines the boundaries of this freedom, stipulating the restrictions and ways of exercising freedom, and also provides for legal guarantees of it (Kosikowski, 2013).

In this sense the prohibitions on performing specific economic activities imposed by the Polish state authorities in order to prevent the spread of the coronavirus SARS-CoV-2 definitively interfere with the sphere of the freedom of economic activity. Therefore, those provisions of the law that establish such prohibitions shall meet the constitutionally stipulated rules of restricting this freedom. 
The Constitution of the Republic of Poland of 2 April $1997^{3}$ determines two criteria for restricting the freedom of economic activity: the restriction shall be imposed "only by means of statute" (the formal criterion) and "only because of important public interest" (the substantive criterion).

Regarding the substantive criterion it should be emphasized that the notion of "public interest" is a typical general clause which is difficult to precisely define and shall be continually redefined ${ }^{4}$. Additionally, the Constitution of the Republic of Poland stipulates that the restriction on this freedom shall be imposed only for "important" public interest. This criterion is considered to be a specific wording of the more general principle of proportionality (Kosikowski, 1998: 227). The Polish Constitutional Tribunal in the judgment of 16 October $2014^{5}$ has indicated four perspectives that should be taken into consideration in the process of verifying whether the criterion of "important public interest" laying down restrictions on the freedom of economic activity was met. Firstly, the interpretation of the "important public interest" cannot disregard the values protected by the principle of a democratic state ruled by law. Secondly, only those restrictions (among those considered useful) on the freedom of economic activity which serve the protection of public safety or public order, or the protection of the environment, public health or freedoms and rights of other persons, do not violate Article 22 of Constitution of the Republic of Poland. In the process of analyzing the restrictions from this perspective, Article 31 paragraph 3 of the Constitution of the Republic of Poland has the crucial meaning. It thoroughly expresses the preferences of the constitutional legislator about the most important manifestations of the public interest that may justify statutory restrictions on constitutional rights and freedoms ${ }^{6}$. Thirdly, the interpretation of the concept of "important public interest" is inextricably linked with the internal hierarchy of constitutional values. Lastly, statutory restriction on this freedom cannot be subject to broad interpretation.

Regarding the formal criterion, which requires that the restrictions on the freedom of economic activity shall be imposed only by means of statute, in the jurisprudence of the Polish Constitutional Tribunal it was clarified that the statutory formula for restricting freedom must have the features of a complete regulation and in no case, in the event of a dispute between an individual and a public authority over the scope or manner of exercising freedoms and rights, may the legal bases for resolving the dispute be detached from the constitutional regulation or be of a rank lower than the statute ${ }^{7}$. On the basis of this criterion it is necessary to add that in the literature (Garlicki, Zubik, 2016; Tuleja, 2021), as well as in the jurisprudence ${ }^{8}$, with regard to the freedom of economic activity, it seems undoubted that the statute 
may contain a specific authorization to issue an executive act (a regulation) to supplement the content of the statute (or more precisely - for the purpose of the implementation of the statute) provided that the statute contains all the basic elements of limiting a given freedom or right. Such authorization shall meet the conditions arising from Article 92 paragraph 1 of the Constitution of the Republic of Poland, i.e. the authorization shall be contained in the statute, shall be established for the purpose of the implementation of the statute, shall specify the authority competent to issue a regulation and the scope of matters to be regulated as well as guidelines concerning the provisions of such an act.

\section{The legal bases of prohibitions on performing specific economic activities introduced to prevent the spread of the coronavirus SARS-CoV-2}

\subsection{General remarks}

The Council of Ministers has not introduced a state of natural disaster in Poland ${ }^{9}$. Instead of that the state authorities decided to create legal bases for implementing measures to prevent the spread of the coronavirus SARSCoV-2 by amending prior existing acts. The analysis of the genesis and development of legal regulations applicable to the prevention of infections and infectious diseases in humans leads to the conclusion that the legislator has created a legal basis for introducing measures in order to combat the COVID-19 pandemic with the use of mechanisms characteristic for the state of exemption without introducing the latter (a sui generis state of emergency; not provided for in the Constitution of the Republic of Poland) (Paśnik, 2020: 69-85).

The legal bases of the prohibitions on performing specific economic activities introduced to combat the COVID-19 pandemic in Poland evolved over time. Therefore, the analysis of the provisions introducing those prohibitions will be conducted separately for two time intervals: (i) for the period from 14 March 2020 to 30 March 2020, and (ii) for the period from 31 March 2020 to 31 May 2021.

\subsection{Prohibitions in the period from 14 March 2020 to 30 March 2020}

In Poland the first prohibitions on performing economic activities in order to prevent the spread of the coronavirus SARS-CoV-2 were introduced effective as of 14 March 2020. Those restrictions were imposed under Reg- 
ulation of the Minister of Health of 13 March 2020 on the introduction of the state of epidemic emergency in the territory of the Republic of Poland ${ }^{10}$. This regulation was repealed by Regulation of the Minister of Health of 20 March 2020 on recalling the state of epidemic emergency in the territory of the Republic of Poland ${ }^{11}$, which came into force on 20 March 2020. Subsequently, the restrictions on the freedom of economic activity were introduced under the Regulation of the Minister of Health of 20 March 2020 on the introduction of the state of epidemic in the territory of the Republic of Poland ${ }^{12}$.

In Regulation of the Minister of Health of 13 March 2020 on the introduction of the state of epidemic emergency in the territory of the Republic of Poland as well as in Regulation of the Minister of Health of 20 March 2020 on the introduction of the state of epidemic in the territory of the Republic of Poland it was indicated that they were adopted on the basis of Article 46 paragraphs 2 and 4 of the Act of 5 December 2008 on preventing and combating infections and infectious diseases in humans ${ }^{13}$.

In accordance with Article 46 paragraph 2 of this Act, if an epidemic emergency or an epidemic occurs in the area of more than one voivodeship, the state of epidemic emergency or state of epidemic is announced and canceled, by way of a regulation, by the minister responsible for health in consultation with the minister responsible for public administration, at the request of the Chief Sanitary Inspector. In accordance with paragraph 4 of this Article in the regulations mentioned in paragraph 1 the following restrictions may be established: 1) temporary restriction on a specific mode of movement, 2) temporary restriction or prohibition of the marketing and use of certain items or food products, 3) temporary restrictions of the functioning of certain institutions or workplaces, 4) prohibition of organizing shows and other gatherings of people, 5) obligation to perform specific sanitary procedures, if their performance is related to the operation of specific production, service, commercial facilities or other facilities, 6) an order to provide real estate, premises, land and to provide means of transport for anti-epidemic activities provided for by anti-epidemic plans, 7) the obligation to carry out preventive vaccinations and the groups of people subject to these vaccinations, the type of protective vaccinations carried out. Those measures may be established having regard to the routes of spread of infection and infectious diseases and the epidemic situation in the area where an epidemic emergency or an epidemic has been declared. In the process of analyzing Article 46 paragraphs 2 and 4 of this Act it should be noted that serious doubts exist as to whether this authorization to issue an executive act fulfills requirements stipulated in Article 92 paragraph 1 of the Consti- 
tution of the Republic of Poland - if only for the very reason that there are no specific guidelines concerning the provisions of such act (see also: Trociuk, 2021: 15-24).

In the two above-mentioned Regulations ${ }^{14}$ the Minister of Health has placed the provisions prohibiting the performance of specific economic activities in chapter 4 entitled "Temporary restrictions on the functioning of certain institutions or workplaces". Such a positioning of this provisions clearly indicates that the intention of the author of those provisions was so that those measures were implemented on the basis of Article 46 paragraph 4 point 3 of the Act of 5 December 2008 on preventing and combating infections and infectious diseases in humans. As was mentioned above, this provision allows introduction of temporary restrictions on the functioning of certain institutions or workplaces, but fails to specify what kind of restrictions may be introduced as well as not stipulating the guidelines concerning the provisions introducing such restrictions.

It should be emphasized that in the Regulation of 13 March 2020 there are rules temporarily prohibiting the performance of economic activity, among others, related to sports, entertainment, and recreation ${ }^{15}$; related to the screening of films or video recording in cinemas, in the open air, and the activities of film clubs ${ }^{16}$; or related to the consumption and serving of drinks ${ }^{17}$. It was also clearly indicated that these restrictions consisted in a complete prohibition of those activities ${ }^{18}$. It should also be underlined that Regulation of 13 March 2020 did not specify the prohibitions introduced by the Act of 5 December 2008 on preventing and combating infections and infectious diseases in humans, but established them itself. The same scheme of rules was adopted in Regulation of 20 March 2020 on the introduction of the state of epidemic in the territory of the Republic of Poland ${ }^{19}$. Based on that, it is questionable whether those restrictions may fall into the category of temporary restrictions on the functioning of certain institutions or workplaces as they rather constitute temporary restrictions (prohibitions) on performing certain economic activity. It is also doubtful whether those provisions can be deemed as the restriction on freedom of economic activity which was enforced in line with the requirements arising from the Article 22 of the Constitution of the Republic of Poland.

\subsection{The prohibitions in the period from 31 March 2020 to 31 May 2021}

Under the Act of 2 March 2020 on special solutions related to the preventing and combating of COVID-19, other infectious diseases and emergencies caused by them ${ }^{20}$ Articles $46 \mathrm{a}$ and $46 \mathrm{~b}$ have been added to the Act 
of 5 December 2008 on preventing and combating infections and infectious diseases in humans and came into force on 8 March 2020.

In accordance with Article 46a of this Act, in the event of an epidemic or an epidemic emergency of a nature and size exceeding the capacity of the competent government administration bodies and local government units, the Council of Ministers may determine, by regulation, on the basis of data provided by the minister responsible for health, the minister responsible for internal affairs, the minister responsible for public administration, the Chief Sanitary Inspector, and voivodes: 1) the endangered area together with an indication of the type of zone in which the epidemic or epidemic emergency occurred, 2) type of applied solutions - to the extent specified in Article 46b - taking into account the scope of applied solutions and taking into account the current possibilities of the state budget and budgets of local government units. Amongst the measures that may be applied, the Article $46 \mathrm{~b}$ point 2 of this Act indicates temporary restrictions of certain scopes of activity of entrepreneurs. It should be emphasized that neither the provisions of the Act of 5 December 2008 on preventing and combating infections and infectious diseases in humans establish certain prohibitions on performing specific economic activities that shall be clarified in the act of a rank lower than a statute nor they indicate the guidelines for such restrictions.

The result of the analysis of the wording of Articles 46a and 46b of the Act of 5 December 2008 on preventing and combating infections and infectious diseases in humans leads to the same conclusion as in the case of the provisions on the basis of which the earlier regulations were adopted, i.e. again, neither the provisions of the statute establish certain prohibitions on performing specific economic activities that shall be clarified in the act of a lower rank nor they indicate the guidelines for such restrictions. Consequently, there are serious doubts as to whether these rules fulfill the requirements stipulated in Article 92 paragraph 1 of the Constitution of the Republic of Poland (Tuleja, 2020: 14; Trociuk, 2021: 15-24).

Article 46a and selected editorial units of Article 46b of the Act of 5 December 2008 on preventing and combating infections and infectious diseases in humans were subsequently indicated in the regulations of Council of Ministers issued as of 31 March 2020 as the legal bases for introducing those regulations. In those regulations the prohibitions on performing specific economic activities to prevent the spread of the coronavirus SARS-CoV-2 were established.

In the period from 31 March 2020 to 31 May 2021 the Council of Ministers issued 14 regulations (each of them have been amended several times) which introduced prohibitions on performing specific economic activities to 
prevent the spread of the coronavirus SARS-CoV-2. Analysis of those regulations leads to the conclusion that the method of expressing (wording) the prohibition has evolved.

While introducing the restrictions on freedom of economic activity to the Regulations of the Council of Ministers adopted in the period from 31 March 2020 to 16 May 2020, the Council of Ministers used the phrase "the temporary restrictions on specific scopes of activity of entrepreneurs" 21. Within this category they established restrictions as to the performance of the given scopes of activity of entrepreneurs. The analysis of particular measures taken under those acts leads to the conclusion that at least some of those included in the category of "the temporary restrictions on specific scopes of activity of entrepreneurs" went far beyond the restriction and became the complete prohibition of performance of the given activity. For example, $\S 8$ paragraph 1 point 1 of the Regulation of the Council of Ministers of 31 March 2020 on the establishment of certain restrictions, orders and prohibitions in connection with the state of epidemic introduced "restrictions on specific scopes of activity of entrepreneurs" which in accordance with the wording $\S 9$ paragraph 1 point 1 of this Regulation "constitute a complete prohibition of activity". The same method of expressing those prohibitions as in the Regulation of the Council of Ministers of 31 March 2020 was used in the remaining Regulations issued till 16 May 2020.

Subsequently, in the Regulations of the Council of Ministers adopted in the period from 29 May 2020 to 9 October 2020, one can realize a change in the method of expressing the prohibition on performing specific economic activities introduced to prevent the spread of the coronavirus SARS-CoV-2. In those Regulations the Council of Ministers clearly stated that certain business activities (e.g. running discos and night clubs) are prohibited until revoked ${ }^{22}$.

In the Regulations of the Council of Ministers issued as of 26 November 2020 one more change can be seen. The Council of Ministers, while establishing the prohibition on performing specific economic activities has determined the date until which the prohibition shall apply instead of the previous phrase "until revoked" 23 . Due to the fact that Article 46b point 2 of the Act of 5 December 2008 on preventing and combating infections and infectious diseases in humans provides for the possibility of establishing temporary restrictions this change shall be assessed positively.

Regardless of the fact that the method of expressing (wording) of the prohibitions has evolved, still it is doubtful whether the provisions under which the prohibitions on performing specific economic activities in order 
to prevent the spread of coronavirus SARS-CoV-2 were introduced can be deemed as restriction on the freedom of economic activity enforced in line with the requirements arising from Article 22 of the Constitution of the Republic of Poland. The main objections in this area remain the same - the restrictions on the freedom of economic activity should have been made by means of statute and - if needed - might have been clarified in the act of a lower rank (but in this case the statute should give clear guidelines as to the content of a regulation).

\section{Case law regarding the prohibitions on performing specific economic activities introduced to prevent the spread of the coronavirus SARS-CoV-2}

Analysis of the jurisprudence of the Polish administrative courts leads to the conclusion that, in accordance with the dominant view, the prohibitions on performing specific economic activities were introduced in a manner that is contrary to the rules for restricting constitutional rights and freedoms. The main reservations regarding the constitutionality of those prohibitions are related to the fact that the statute fails to independently define the basic elements of restrictions and the authorisations contained in the Articles 46 and 46a of the Act of 5 December 2008 on preventing and combating infections and infectious diseases in humans do not fulfill the requirements stipulated in Article 92 paragraph 1 of the Constitution of the Republic of Poland. As it was accurately indicated in the judgment of Provincial Administrative Court in Opole of 27 October 2020 "[w]hen limiting constitutional rights and freedoms under Article 31 paragraph 3 of the Constitution of the Republic of Poland, the completeness and the degree of detail of the statutory regulation must be significantly increased. Therefore, it should be emphasized that the provisions established at the level of the regulation, apart from the fact that they cannot regulate fundamental constitutional freedoms and rights, must also meet the conditions set out in Article 92 paragraph 1 of the Constitution of the Republic of Poland. A regulation must therefore be issued by an authority specified in the Constitution, on the basis of specific authorization contained in a statute, and for the purpose of its implementation. (...). However, the above rules were broken by introducing regulations related to the preventing and combating the epidemic caused by the SARS-CoV-2 virus" ${ }^{24}$. It was also emphasized that "[w]hile the assessed prohibitions, orders and restrictions were substantively justified, the manner of their introduction led to the violation of 
basic constitutional standards and rights in the field of freedom of economic activity". This view has also been replicated in the subsequent judgments of Provincial Administrative Courts ${ }^{25}$. On the contrary, there is also a judgment in which the administrative court has come to the completely different conclusion - in the judgement of Provincial Administrative Court in Bydgoszcz of 17 November 2020 the court has stated that "the prohibition on performing specific economic activities had been introduced on the basis of the statute which authorized the Council of Ministers to specify restrictions, orders and prohibitions in connection with the state of epidemic. Such a statutory procedure was fully justified, because it allows for an ongoing response to the dynamically changing epidemic situation and the parliament's action in this area by issuing statutes would not guarantee the effectiveness of combating the epidemic, even taking into account the length of the legislative process" 26 . In other words, the grounds for this judgment suggest that the fact that the prohibitions were substantively justified makes the manner of their introduction irrelevant. The view presented in the last judgement raises serious reservations because the sole fact that the prohibitions were substantively justified cannot lead to the conclusion that the manner of their introduction is irrelevant.

\section{Conclusions}

The analysis contained in this paper leads to the conclusion that, instead of declaring a state of natural disaster, the Polish legislature and executive have taken steps in order to introduce measures limiting constitutional rights and freedoms with the use of mechanisms characteristic for the state of exemption without introducing the latter. In the light of the constitutional requirements for restricting the freedom of economic activity, such a method of introducing prohibitions on performing specific economic activities to prevent the spread of the coronavirus SARS-CoV-2 raises serious reservations as to its compliance with the Constitution of the Republic of Poland. The main source of those reservations is that the prohibitions on performing specific economic activities were introduced with the legal act of a rank lower than a statute. Moreover, the provisions of the Act of 5 December 2008 on preventing and combating infections and infectious diseases in humans do not fulfill the requirements stipulated in Article 92 paragraph 1 of the Constitution of the Republic of Poland as to the expressing authorization to issue the regulations. Lastly, the regulations do not specify the prohibitions introduced by the statue but establish them themselves. 


\title{
Legality of Prohibitions on Performing Specific Economic Activities...
}

\author{
$\mathrm{N} \mathrm{O} \mathrm{T} \mathrm{E} \mathrm{S}$
}

${ }^{1}$ On the concept of the freedom of economic activity see e.g. Kosikowski, 1998: 215.

${ }^{2}$ Such a view is also presented in the jurisprudence - see e.g.: the judgment of the Provincial Administrative Court in Warsaw of 15 April 2010, VI SA/Wa 338/10 and the judgment of the Supreme Administrative Court of 29 September 2011, II GSK 933/10.

3 Journal of Laws no. 78 item 483 as amended; hereinafter referred to as the Constitution of the Republic of Poland.

4 On the notion of "public interest" see among others: Modliński, 1932; Żurawik, 2013; Żurawik in: Hauser, Niewiadomski, Wróbel, 2013: 418; Duda, 2008. See also: KorycińskaRządca, 2020: 41-48 and the bibliography indicated therein.

5 Judgment of the Constitutional Tribunal of 16 October 2014, SK 20/12, in Polish published in the Journal of Laws 2014 item 1458.

${ }^{6}$ In accordance with Article 31 paragraph 3 of the Constitutional of the Republic of Poland: Any restriction upon the exercise of constitutional freedoms and rights may be imposed only by statute, and only when necessary in a democratic state for the protection of its security or public order, or to protect the natural environment, health or public morals, or the freedoms and rights of other persons. Such restrictions shall not violate the essence of freedoms and rights.

7 Judgment of the Constitutional Tribunal of 19 May 1998, U 5/97, in Polish published in the Journal of Laws 1998 number 67 item 444. See also among others: judgment of the Constitutional Tribunal of 7 November 2000, K 16/00, in Polish published in the Journal of Laws 2000 number 96 item 1056; judgment of the Constitutional Tribunal of 19 February 2002 r., U 3/01, in Polish published in the Journal of Laws 2002 number 19 item 197; judgment of the Constitutional Tribunal of 26 April 2016, U 1/15, in Polish published in the Journal of Laws 2016 item 1236.

8 Judgment of the Constitutional Tribunal of 10 April 2001, U 7/00, in Polish published in the Journal of Laws 2001 no. 36 item 422; judgment of the Constitutional Tribunal of 25 July 2006, P 24/05, in Polish published in the Journal of Laws 2006 no. 141 item 1012.

9 On the prerequisites for introducing a state of natural disaster and legal consequences of introducing one see Paśnik, 2020: 78-81 and the literature indicated therein. See also: Tuleja, 2020: 14 .

10 Journal of Laws 2020 item 433.

11 Journal of Laws 2020 item 490.

12 Journal of Laws 2020 item 491 as amended.

13 Journal of Laws of 2019 item 1239 as amended.

14 I.e. Regulation of the Minister of Health of 13 March 2020 on the introduction of the state of epidemic emergency in the territory of the Republic of Poland and Regulation of the Minister of Health of 20 March 2020 on the introduction of the state of epidemic in the territory of the Republic of Poland.

$15 \S 5$ paragraph 1 point 1 letter d of Regulation of 13 March 2020.

$16 \S 5$ paragraph 1 point 1 letter e of Regulation of 13 March 2020.

$17 \S 5$ paragraph 1 point 1 letter f of Regulation of 13 March 2020.

$18 \S 6$ paragraph 1 point 1 of Regulation of 13 March 2020. 


\section{Paulina Korycińska-Rzadca}

19 See: $\S 6$ and 7 of Regulation of 20 March 2020.

20 Consolidated version: Journal of Laws 2020 item 1842 as amended.

21 See e.g. $\S 8$ paragraph 1 point 1 of the Regulation of the Council of Ministers of 31 March 2020 on the establishment of certain restrictions, orders and prohibitions in connection with the state of epidemic, Journal of Laws 2020 item 556 as amended; $\S 8$ paragraph 1 point 1 of the Regulation of the Council of Ministers of 19 April 2020 on the establishment of certain restrictions, orders and prohibitions in connection with the state of epidemic, Journal of Laws 2020 item 697 as amended; $\S 7$ paragraph 1 point 1 of the Regulation of the Council of Ministers of 2 May 2020 on the establishment of certain restrictions, orders and prohibitions in connection with the state of epidemic, Journal of Laws 2020 item 792 as amended; $\S 7$ paragraph 1 point 1 of the Regulation of the Council of Ministers of 16 May 2020 on the establishment of certain restrictions, orders and prohibitions in connection with the state of epidemic, Journal of Laws 2020 item 878 as amended.

22 See e.g. $\S 6$ paragraph 1 of the Regulation of the Council of Ministers of 29 May 2020 on the establishment of certain restrictions, orders and prohibitions in connection with the state of epidemic, Journal of Laws 2020 item 964 as amended; $\S 6$ paragraph 1 of the Regulation of the Council of Ministers of 19 June 2020 on the establishment of certain restrictions, orders and prohibitions in connection with the state of epidemic, Journal of Laws 2020 item 1066 as amended; $\S 7$ paragraph 1 of the Regulation of the Council of Ministers of 7 August 2020 on the establishment of certain restrictions, orders and prohibitions in connection with the state of epidemic, Journal of Laws 2020 item 1356 as amended; $\S 6$ paragraph 1 of the Regulation of the Council of Ministers of 9 October 2020 on the establishment of certain restrictions, orders and prohibitions in connection with the state of epidemic, Journal of Laws 2020 item 1758 as amended.

23 See e.g.: $\S 10$ paragraph 1 of the Regulation of the Council of Ministers of 26 November 2020 on the establishment of certain restrictions, orders and prohibitions in connection with the state of epidemic, Journal of Laws 2020 item 2091; $\S 10$ paragraph 1 of the Regulation of the Council of Ministers of 1 December 2020 on the establishment of certain restrictions, orders and prohibitions in connection with the state of epidemic, Journal of Laws 2020 item 2132; $\S 10$ paragraph 1 of the Regulation of the Council of Ministers of 21 December 2020 on the establishment of certain restrictions, orders and prohibitions in connection with the state of epidemic, Journal of Laws 2020 item 2316 as amended; $\S 9$ paragraph 1 of the Regulation of the Council of Ministers of 26 February 2021 on the establishment of certain restrictions, orders and prohibitions in connection with the state of epidemic, Journal of Laws 2021 item 447; § 9 paragraph 1 of the Regulation of the Council of Ministers of 19 March 2021 on the establishment of certain restrictions, orders and prohibitions in connection with the state of epidemic, Journal of Laws 2021 item 512 as amended; $\S 9$ paragraph 1 of the Regulation of the Council of Ministers of 6 May 2021 on the establishment of certain restrictions, orders and prohibitions in connection with the state of epidemic, Journal of Laws 2021 item 861 as amended.

24 Judgment of the Provincial Administrative Court in Opole of 27 October 2020, II SA/Op 219/20.

25 See e.g.: judgment of the Provincial Administrative Court in Szczecin of 11 December 2020, II SA/Sz 765/20; judgment of the Provincial Administrative Court in Kraków of 12 April 2021, III SA/Kr 1306/20; judgment of the Provincial Administrative Court in Kraków of 12 April 2021, III SA/Kr 1307/20; judgment of the Provincial Administrative Court in Gliwice of 27 April 2021, III SA/Gl 33/21.

26 Judgment of the Provincial Administrative Court in Bydgoszcz of 17 November 2020, II SA/Bd 834/20. 
Legality of Prohibitions on Performing Specific Economic Activities...

R E F E R E N C E S

Garlicki, L., Zubik, M. (2016). Comment to Article 22. In M. Derlatka, K. Działocha, P. Sarnecki, W. Sokolewicz, J. Trzciński, M. Wiącek, L. Garlicki, M. Zubik, Konstytucja Rzeczypospolitej Polskiej. Komentarz. Tom I, wyd. II. Warsaw.

Duda, A.S. (2008). Interes prawny w polskim prawie administracyjnym. Warsaw.

Korycińska-Rządca, P. (2020). Ochrona tajemnic strony postępowania antymonopolowego w sprawach praktyk ograniczajacych konkurencję. Warsaw.

Kosikowski, C. (1998). Zasada wolności działalności gospodarczej. In W. Sokolewicz (ed.) Zasady podstawowe polskiej konstytucji. Warsaw.

Kosikowski, C. (2013). Comment to Article 6. In C. Kosikowski. Ustawa o swobodzie działalności gospodarczej. Komentarz. Warsaw.

Leszczyńska, B., Piszcz, A. (2008). Zasada wolności działalności gospodarczejzasada prawa prywatnego czy publicznego? Białostockie Studia Prawnicze 3.

Modliński, E. (1932). Pojęcie interesu publicznego w prawie administracyjnym. Warsaw.

Paśnik, J. (2020). Kilka refleksji o regulacjach stanu epidemii jako sui generis pozakonstytucyjnego stanu nadzwyczajnego. Przegląd Prawa Publicznego 11.

Trociuk, S. (2021). Prawa i wolności w stanie epidemii, Warsaw.

The Ministry of Health. (2020). Od dziś wprowadzimy stan zagrożenia epidemicznego. https://www.gov.pl/web/zdrowie/pierwszy-przypadek-koronawirusaw-polsce (31.05.2021).

Tuleja, P. (2020). Pandemia COVID-19 a konstytucyjne stany nadzwyczajne. Palestra 9.

Tuleja, P. (2021). Comment to Article 22. In P. Czarny, M. Florczak-Wątor, B. Naleziński, P. Radziewicz, P. Tuleja. Konstytucja Rzeczypospolitej Polskiej. Komentarz. LEX/el.

Walaszek-Pyzioł, A. (1994). Swoboda działalności gospodarczej. Kraków.

Hauser, R., Niewiadomski, Z., Wróbel, A. (eds.). Publiczne prawo gospodarcze. System Prawa Administracyjnego, vol. 8B. Warsaw.

Żurawik, A. (2013). Interes publiczny w prawie gospodarczym. Warsaw.

\section{Legal acts}

Act of 5 December 2008 on preventing and combating infections and infectious diseases in humans, Journal of Laws of 2019 item 1239 as amended.

Act of 2 March 2020 on special solutions related to the preventing and combating of COVID-19, other infectious diseases and emergencies caused by them. Consolidated version: Journal of Laws 2020 item 1842 as amended.

Constitution of the Republic of Poland of 2 April 1997, Journal of Laws no. 78 item 483 as amended. 
Regulation of the Minister of Health of 13 March 2020 on the introduction of the state of epidemic emergency in the territory of the Republic of Poland, Journal of Laws 2020 item 433.

Regulation of the Minister of Health of 20 March 2020 on recalling the state of epidemic emergency in the territory of the Republic of Poland, Journal of Laws 2020 item 490.

Regulation of the Minister of Health of 20 March 2020 on the introduction of the state of epidemic in the territory of the Republic of Poland, Journal of Laws 2020 item 491 as amended.

Regulation of the Council of Ministers of 31 March 2020 on the establishment of certain restrictions, orders and prohibitions in connection with the state of epidemic, Journal of Laws 2020 item 556 as amended.

Regulation of the Council of Ministers of 19 April 2020 on the establishment of certain restrictions, orders and prohibitions in connection with the state of epidemic, Journal of Laws 2020 item 697 as amended.

Regulation of the Council of Ministers of 2 May 2020 on the establishment of certain restrictions, orders and prohibitions in connection with the state of epidemic, Journal of Laws 2020 item 792 as amended.

Regulation of the Council of Ministers of 16 May 2020 on the establishment of certain restrictions, orders and prohibitions in connection with the state of epidemic, Journal of Laws 2020 item 878 as amended.

Regulation of the Council of Ministers of 29 May 2020 on the establishment of certain restrictions, orders and prohibitions in connection with the state of epidemic, Journal of Laws 2020 item 964 as amended.

Regulation of the Council of Ministers of 19 June 2020 on the establishment of certain restrictions, orders and prohibitions in connection with the state of epidemic, Journal of Laws 2020 item 1066 as amended.

Regulation of the Council of Ministers of 7 August 2020 on the establishment of certain restrictions, orders and prohibitions in connection with the state of epidemic, Journal of Laws 2020 item 1356 as amended.

Regulation of the Council of Ministers of 9 October 2020 on the establishment of certain restrictions, orders and prohibitions in connection with the state of epidemic, Journal of Laws 2020 item 1758 as amended.

Regulation of the Council of Ministers of 26 November 2020 on the establishment of certain restrictions, orders and prohibitions in connection with the state of epidemic, Journal of Laws 2020 item 2091.

Regulation of the Council of Ministers of 1 December 2020 on the establishment of certain restrictions, orders and prohibitions in connection with the state of epidemic, Journal of Laws 2020 item 2132.

Regulation of the Council of Ministers of 21 December 2020 on the establishment of certain restrictions, orders and prohibitions in connection with the state of epidemic, Journal of Laws 2020 item 2316 as amended. 
Regulation of the Council of Ministers of 26 February 2021 on the establishment of certain restrictions, orders and prohibitions in connection with the state of epidemic, Journal of Laws 2021 item 447.

Regulation of the Council of Ministers of 19 March 2021 on the establishment of certain restrictions, orders and prohibitions in connection with the state of epidemic, Journal of Laws 2021 item 512 as amended.

Regulation of the Council of Ministers of 6 May 2021 on the establishment of certain restrictions, orders and prohibitions in connection with the state of epidemic, Journal of Laws 2021 item 861 as amended.

\section{Case law}

Judgment of the Constitutional Tribunal of 19 May 1998, U 5/97. In Polish published in the Journal of Laws 1998 number 67 item 444.

Judgment of the Constitutional Tribunal of 7 November 2000, K 16/00. In Polish published in the Journal of Laws 2000 number 96 item 1056.

Judgment of the Constitutional Tribunal of 10 April 2001, U 7/00. In Polish published in the Journal of Laws 2001 no. 36 item 422.

Judgment of the Constitutional Tribunal of 19 February 2002, U 3/01. In Polish published in the Journal of Laws 2002 number 19 item 197.

Judgment of the Constitutional Tribunal of 25 July 2006, P 24/05. In Polish published in the Journal of Laws 2006 no. 141 item 1012.

Judgment of the Constitutional Tribunal of 16 October 2014, SK 20/12. In Polish published in Journal of Laws 2014 item 1458.

Judgment of the Constitutional Tribunal of 26 April 2016, U 1/15. In Polish published in the Journal of Laws 2016 item 1236.

Judgment of the Provincial Administrative Court in Bydgoszcz of 17 November 2020, II SA/Bd 834/20. Retrived from: https://orzeczenia.nsa.gov.pl/ (31.05.2021).

Judgment of the Provincial Administrative Court in Gliwice of 27 April 2021, III SA/Gl 33/21. Retrived from: https://orzeczenia.nsa.gov.pl/ (31.05.2021).

Judgment of the Provincial Administrative Court in Kraków of 12 April 2021, III SA/Kr 1306/20. Retrived from: https://orzeczenia.nsa.gov.pl/ (31.05.2021).

Judgment of the Provincial Administrative Court in Kraków of 12 April 2021, III SA/Kr 1307/20. Retrived from: https://orzeczenia.nsa.gov.pl/ (31.05.2021).

Judgment of the Provincial Administrative Court in Opole of 27 October 2020, II SA/Op 219/20. Retrived from: https://orzeczenia.nsa.gov.pl/ (31.05.2021).

Judgment of the Provincial Administrative Court in Szczecin of 11 December 2020, II SA/Sz 765/20. Retrived from: https://orzeczenia.nsa.gov.pl/ (31.05.2021).

Judgment of the Provincial Administrative Court in Warsaw of 15 April 2010, VI SA/Wa 338/10. Retrived from: https://orzeczenia.nsa.gov.pl/ (31.05.2021).

Judgment of the Supreme Administrative Court of 29 September 2011, II GSK 933/10. Retrived from: https://orzeczenia.nsa.gov.pl/ (31.05.2021). 